\title{
Chemical, rheological, and organoleptic analysis of cow and buffalo milk mozzarella cheese
}

\author{
Abdul Rauf BHAT ${ }^{1, \mathrm{a}}$, Atta Hussain SHAH ${ }^{1, \mathrm{~b}}$, Mansoor AYOOB ${ }^{1, \mathrm{c}}$, Muhammad Faisal AYOOB ${ }^{2,3, \mathrm{~d}, \varpi,}$ \\ Farrukh SALEEM ${ }^{3, e}$, Muhammad Mohsin ALI ${ }^{3, f}$, Muhammad FAYAZ ${ }^{3, g}$

\begin{abstract}
${ }^{1}$ Department of Animal Product Technology, Faculty of Animal Husbandry and Veterinary Sciences, Sindh Agriculture University Tando Jam-70060, Pakistan. ${ }^{2}$ Department of Veterinary Pathology, Faculty of Animal Husbandry and Veterinary Sciences, Sindh Agriculture University Tando Jam-70060, Pakistan. ${ }^{3}$ National Veterinary Laboratories, Ministry of National Food Security and Research Islamabad-44000, Pakistan

aORCID: 0000-0002-1624-0338; ' ORCID: 0000-0003-4558-3660; ' ORCID: 0000-0003-4991-8069;

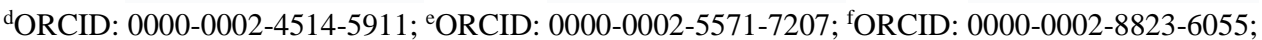 \\ gORCID:0000-0001-6374-4849
}

Corresponding author: ayoob.faisal@yahoo.com

Received date: 20.10 .2020 - Accepted date: 08.04.2021

\begin{abstract}
This research was aimed to determine the impact of milk source on mozzarella cheese's chemical, rheological, and organoleptic characteristics. A total of 10 lots of cow and buffalo milk mozzarella cheese each were prepared. Prominent milk source influence on the chemical characteristics and calorific values of mozzarella cheese was determined. A decrease in moisture content and an increase in fat, protein, ash, and calorific values were noted in mozzarella cheese against their respective milk. Moisture content in cow milk mozzarella cheese (CMM) was considerably higher than buffalo milk mozzarella cheese (BMM). Average fat, ash content and calorific values appeared considerably high in BMM cheese compared to CMM cheese but protein content was recorded inverse and statistically non-significant $(\mathrm{P}>0.05)$. The average meltability was slightly higher in CMM cheese and the stretchiness of CMM cheese appeared significantly high from that of BMM cheese. BMM cheese was remarkably high in yield in contrast to that of CMM cheese. Appearance, flavor, and body/texture scores were slightly higher in CMM cheese as compared to BMM cheese. Regardless, the average benefit computed for BMM cheese was high in comparison to CMM cheese, the differences among them were statistically non-significant. The present study concludes that buffalo milk is better to produce mozzarella cheese with higher calorific values, better yield, and with more economic values, while cow milk is better to produce mozzarella cheese with the more proteinous, enhanced stretchiness, and better organoleptic quality.
\end{abstract}

Keywords: Buffalo milk, cow milk, Mozzarella cheese, organoleptic, rheological.

\section{Introduction}

Mozzarella cheese is popular around the world due to its use for pizza topping. Its rheological (melting and stretching) properties, softness and appearance are best for making pizzas. Mozzarella cheese belongs to 'pasta filata' class that requires a skillful stretch of the coagulated milk in lukewarm water to achieve smoothness. It is a product made from buffalo-milk, by coagulating the milk casein by direct addition of lactic acid or adventitious microorganisms with rennet or a similar enzyme from which moisture was extracted by incising, cooking or pressing, and then matured at appropriate temperatures and humidity (19). Bacterial culture is used to convert milk sugar (lactose) into lactic acid. The production rate of acid is important in assessing the consistency of the cheese (7). Mozzarella cheese is a savory and nutritious milk product.
However, its quality depends on the physical properties, especially the ability to melt, elasticity, color, and free oil production. Differences in processing conditions, temperature, storage time, and milk quality can affect the functional properties of mozzarella cheese (2). The fat and casein contents contained in a curd during processing are typically high in Mozzarella cheese, which contains reasonably little quantities of water-miscible components (whey proteins, milk sugar, and water-miscible vitamins) that are primarily found in the wey. Mozzarella cheese is a rich source of nutrients, proteins, vitamins, fat, and carbohydrates (16). It provides many health benefits and can protect against gout, which causes uric acid crystals to develop in the joints (17). The calcium present in mozzarella also contributes to weight loss and protects from breast cancer and metabolic disorders that raise the 
risk of cardiovascular disease or attack (15). For mozzarella cheese, buffalo milk is favored due to its high fat, vitamin A, calcium, and low cholesterol content. Rheological properties (meltablility and stretchiness), oilfree production and browning are the chief functional attributes of mozzarella cheese which are greatly reliant on the basic formation and composition of the cheese. The resulting cheese functionality is determined by the moisture content, fat percentage, salt, and mineral especially calcium, $\mathrm{pH}$, and proteolysis. These properties perform a key part in consumer expectations about the consistency of the cheese. Eating habits are changing very rapidly through out the world. This has resulted in more pizza consumption and other similar fast foods. As a result, pizza-usable cheese has become increasingly relevant commercially in the dairy industry, where various types of cheeses with different labels are available on the local market. Besides, preparation and quality assessment of mozzarella cheese from two different milk sources can improve dairy industries to select the milk that may be the best for producing mozzarella cheese. This study had been aimed to examine the chemical, rheological and organoleptic attributes of mozzarella cheese produced from buffalo and cow milk. Also, its calorific values, yield, and economic impact have been measured.

\section{Materials and Methods}

Collection of milk samples and chemicals required for mozzarella cheese making: Buffalo and cow milk collected from the Livestock Experiment Station, Sindh Agriculture University Tandojam. It was first strained through a muslin cloth as soon as the milk was collected, and the volume was measured. Approximately $250 \mathrm{ml}$ of milk was transferred for analysis to sample bottles; the rest of the milk was used for making mozzarella cheese. During mozzarella cheese production, the tablet rennet enzyme (Lahore Farmer Cheese Company), sodium chloride $(\mathrm{NaCl})$ of laboratory-grade (E. Merck Darmstadt Company) for preparing Brine solution and Artisan starter culture prepared at the Animal Products Technology Department were used.

\section{Analysis of milk samples}

Moisture content: Association of Official Analytical Chemists (5) procedure was adopted to calculate moisture percentage with the help of the following formula.

$$
\begin{aligned}
& \text { Moisture } \%=\frac{W_{2}-W_{3}}{W_{2}-W_{1}} \times \mathbf{1 0 0} \\
& \text { Where, } \\
& \text { W1 = Empty plate weight } \\
& \text { W2 = plate weight }+ \text { sample weight } \\
& \text { W3 = plate weight }+ \text { dried sample weight }
\end{aligned}
$$

Total protein content: Protein content was determined according to the method of British standards
Institution (9). The nitrogen percentage was calculated using the following formula.

$$
\mathrm{N} \%=\frac{1.4\left(\mathrm{~V}_{1}-\mathrm{V}_{2}\right) \times \text { Normality of } \mathrm{HCl}}{\text { Weight of sample taken } \times \text { weight of diluted sample }}
$$

Where,

V1 = value of titration

$\mathbf{V} 2$ = value of the blank sample

By considering the nitrogen percentage present in the milk as protein, the protein content was calculated by conversion of nitrogen percentage using the following formula.

Protein percentage $=\mathrm{N} \% \times$ Conversion Factor $(\mathrm{CF})$

$(\mathrm{CF}=100 / \mathrm{N} \%$, the protein of milk and dairy products (i.e. 15.66).

Fat content: Abegao et al. (1) explained the Gerber method to determine the fat content present in the milk and other dairy products by using a butyrometer, which was used in the present study.

Ash content: Ash content was determined according to the method of AOAC (5) by applying the following formula.

$$
\text { Ash content } \%=\frac{\text { Ashed sample }}{\text { Sample taken }} \times 100
$$

Preparation of starter culture: Starter culture (Artisan) was prepared in buffalo skimmed milk by inoculation of a portion of the previously rendered Dahi (3 percent) and purified by repeating it several times. The milk was heated for 10 minutes $\left(90^{\circ} \mathrm{C}\right)$, cooled to $45^{\circ} \mathrm{C}$, and inoculated with previously made Dahi $(3 \%)$ incubated $\left(40 \pm 2{ }^{\circ} \mathrm{C}\right)$ until the $\mathrm{pH}$ fell to 4.5 or 4.7 . During the time of experimental research, this culture was then preserved as a mother culture.

Preparation of brine solution $(2.5 \% \mathrm{NaCl}): 2.5 \%$ (w/v) Sodium chloride solution was prepared by dissolving $25 \mathrm{~g} \mathrm{NaCl}$ into $1000 \mathrm{ml}$ of distilled water. The brine solution was kept at $4{ }^{\circ} \mathrm{C}$ in a refrigerated till use.

Preparation of mozzarella cheese: Dave et al. (12) method for mozzarella cheese preparation was used and the basic manufacturing steps are illustrated in Figure 1.

\section{Analysis of mozzarella cheese}

Preparation of cheese sample: The cheese sample (100 g) was mashed in a pestle mortar or grinder, to make homogeneous and bring it to a temperature of $25^{\circ} \mathrm{C}$.

Moisture, total protein, fat, and ash content: Moisture, total protein, fat, and ash contents were examined according to the method as described in this section earlier, respectively. However, a minor modification has been made in the case of protein and fat content determination. The sample weight was decreased to $2 \mathrm{~g}$ against $5 \mathrm{~g}$ in total protein assay and for fat $3 \mathrm{~g}$ instead of $11 \mathrm{ml}$. The strength of sulfuric acid was also reduced to a $65 \%$ level. 


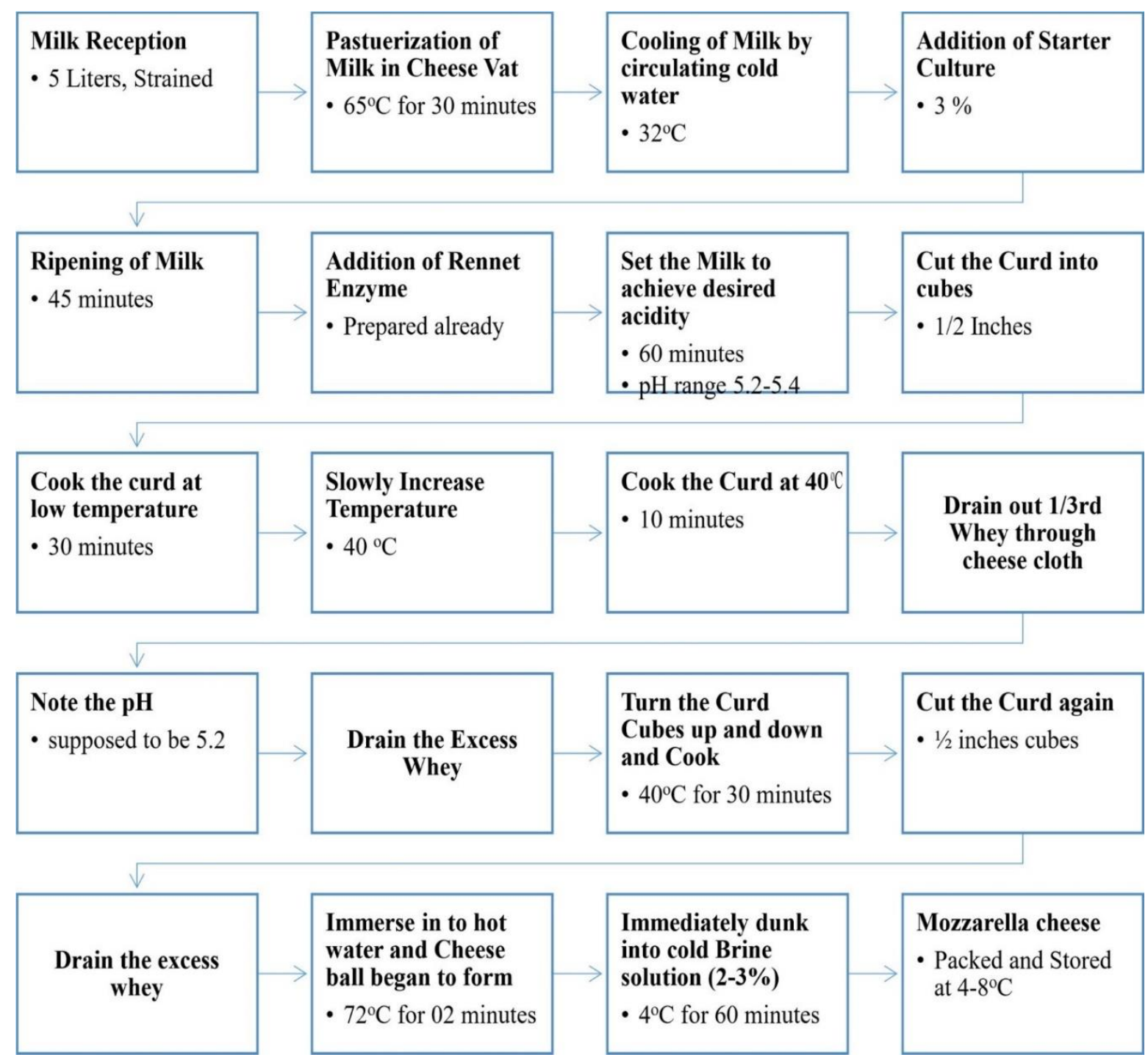

Figure 1. Flow chart showing the basic methodology of Mozzarella cheese making.

Meltability: The method described by Caissokolinska and Pikul (10) with slight alteration was used to examine the meltability of mozzarella cheese. Small pieces of cheese samples were made and measured their initial diameter with the help of a vernier caliper. Then cheese specimen was heated in the microwave oven at 60 ${ }^{\circ} \mathrm{C}$ for 5 minutes. After that cheese specimen was cooled to room temperature for $30 \mathrm{~min}$ and measured melted cheese diameter. Meltability was determined by using the following formula.

Meltability $=$ Melted cheese diameter - Initial diameter of cheese specimen

Stretchiness: The cheese was removed from the refrigerated storage $\left(4^{\circ} \mathrm{C}\right)$ and cut into small pieces, then ground at ambient temperature in a blender (Model No. T.S. 696. E G. Anex Germany product gmbH). The size of the particle in the cheese was around $5 \mathrm{~mm} .200 \mathrm{~g}$ of ground cheese was placed in a glass container and heated at $60{ }^{\circ} \mathrm{C}$ for 5 minutes. The cheese specimen was manually stretched with a finger until the string of cheese was almost to split. At that time measured the cheese string length with the measuring scale. Stretchiness was measured by using the following formula.

Stretchiness $=$ stretched cheese string length - initial cheese particle length

Organoleptic Properties: A jury of six judges conducted the organoleptic analysis to determine the cheese sample. The judges included teachers and M. Phil students from the Animal Products Technology Department. The vocabulary used for the product definition consisted of appearance, color, flavor, and body/texture with the hedonic scale of $15,10,45$, and 30 respectively (22).

Cheese yield: Cheese yield was determined by the following formula as reported by Sulieman et al (24).

$$
\text { Yield } \%=\frac{\text { weight of cheese }}{\text { weight of milk }} \times 100
$$


Calorific values: Calorific values of cheese samples were calculated by using energy conversion factors of major components like 4 for each protein and carbohydrates and 9 for fat as reported by Al-Amiri et al. (3).

Economics: The total per-unit cost of ingredients and unforeseen expenses during mozzarella cheese making were gathered and based on those expenditures, the expected benefit was computed by the following formula.

Per unit current marketing cost of the product- per unit manufacture cost of the product.

Statistical analysis: The result data gathered were processed, collated, and analyzed using Student Edition of Statistics (SXW), Version 8.1 (copyright 2005 Analytical Software, U.S.A). A descriptive statistics of summary statistics and one-way analysis of variance tests were used to detect group differences, and the results were further analyzed with the least significant difference (LSD) test at 0.05 levels in case of substantial variation between groups.

\section{Results}

Influence of milk source on the chemical composition of mozzarella cheese

Moisture content: The minimum moisture content of BMM cheese was observed as $44 \%$ and the maximum $51 \%$, while the minimum moisture content of $\mathrm{CMM}$ cheese was recorded as $51 \%$ and the maximum $58 \%$. A remarkable $(\mathrm{P}<0.05)$ variation was recorded between the moisture content of cow milk and buffalo milk as cheese base milk. The average moisture content $(87.40 \pm 0.27 \%)$ in cow milk appeared considerably high compared to that of buffalo milk $(84.0 \pm 0.34 \%)$. A similar trend of moisture content was noted in mozzarella cheese prepared from each cow and buffalo milk. CMM cheese remained significantly $(\mathrm{P}<0.05)$ high in moisture content $(54.10 \pm$ $0.64 \%)$ in contrast to that of BMM cheese $(46.70 \pm$ $0.69 \%)$. Further results revealed that average moisture content in both BMM and/or CMM cheese decreased significantly from that of their corresponding milk (Figure 2, Table 1).

Table 1. Mean values of chemical, rheological and organoleptic attributes of buffalo and cow milk mozzarella cheese (Mean \pm SEM).

\begin{tabular}{|c|c|c|c|c|c|}
\hline Attributes & Buffalo Milk & Cow Milk & $\begin{array}{c}\text { Buffalo Milk } \\
\text { Mozzarella Cheese }\end{array}$ & $\begin{array}{c}\text { Cow Milk } \\
\text { Mozzarella Cheese }\end{array}$ & $\mathbf{P}$ \\
\hline \multicolumn{6}{|l|}{ Chemical Analysis } \\
\hline Moisture contents (\%) & $84.0 \pm 0.34^{\mathrm{b}}$ & $87.40 \pm 0.27^{\mathrm{a}}$ & $46.70 \pm 0.69^{d}$ & $54.10 \pm 0.64^{\mathrm{c}}$ & 1.476 \\
\hline $\begin{array}{l}\text { Total Protein } \\
\text { (\%DMB) }\end{array}$ & $26.92 \pm 0.92^{\mathrm{b}}$ & $23.80 \pm 0.49^{b}$ & $42.87 \pm 1.39^{\mathrm{a}}$ & $45.27 \pm 1.65^{\mathrm{a}}$ & 3.44 \\
\hline $\begin{array}{l}\text { Total Fat } \\
\text { (\%DMB) }\end{array}$ & $36.34 \pm 1.36^{\mathrm{c}}$ & $28.18 \pm 0.61^{\mathrm{d}}$ & $46.32 \pm 1.02^{\mathrm{a}}$ & $41.82 \pm 1.31^{\mathrm{b}}$ & 3.204 \\
\hline Ash contents (\% DMB) & $4.27 \pm 0.21^{\mathrm{b}}$ & $4.67 \pm 0.27^{\mathrm{b}}$ & $6.52 \pm 0.24^{\mathrm{a}}$ & $6.23 \pm 0.28^{\mathrm{a}}$ & 0.72 \\
\hline \multicolumn{6}{|l|}{ Rheological Analysis } \\
\hline Meltability (cm) & - & - & $2.87 \pm 0.08^{\mathrm{b}}$ & $3.41 \pm 0.13^{\mathrm{a}}$ & 0.002 \\
\hline Stretchiness (cm) & - & - & $6.45 \pm 0.36^{\mathrm{b}}$ & $7.65 \pm 0.33^{\mathrm{a}}$ & 0.027 \\
\hline \multicolumn{6}{|l|}{ Organoleptic Analysis } \\
\hline $\begin{array}{c}\text { Appearance } \\
\text { (max score 15) }\end{array}$ & - & - & $10.81 \pm 0.36^{\mathrm{a}}$ & $11.86 \pm 0.41^{\mathrm{a}}$ & 0.074 \\
\hline $\begin{array}{c}\text { Color } \\
(\max . \text { score 10) }\end{array}$ & - & - & $6.80 \pm 0.30^{\mathrm{b}}$ & $7.70 \pm 0.28^{\mathrm{a}}$ & 0.041 \\
\hline $\begin{array}{l}\text { Flavor/ Taste } \\
\text { (max score 45) }\end{array}$ & - & - & $34.80 \pm 0.79^{\mathrm{a}}$ & $35.10 \pm 1.13^{\mathrm{a}}$ & 0.825 \\
\hline $\begin{array}{l}\text { Body/ Texture (max } \\
\text { score 30) }\end{array}$ & - & - & $24.56 \pm 0.77^{\mathrm{a}}$ & $24.70 \pm 0.54^{\mathrm{a}}$ & 0.883 \\
\hline $\begin{array}{c}\text { Mozzarella Cheese } \\
\text { Yield (\%) }\end{array}$ & - & - & $16.95 \pm 1.29^{\mathrm{a}}$ & $12.68 \pm 0.93^{\mathrm{b}}$ & 0.028 \\
\hline $\begin{array}{l}\text { Calorific value } \\
\text { (Kcal/100g) }\end{array}$ & $89.79 \pm 1.14^{\mathrm{c}}$ & $65.72 \pm 1.33^{\mathrm{d}}$ & $318.49 \pm 6.42^{\mathrm{a}}$ & $268.83 \pm 5.08^{\mathrm{b}}$ & 12.01 \\
\hline
\end{tabular}

$\overline{\text { a,b,c,d }}$ Values within a row with different superscripts differ significantly at $\mathrm{P}<0.05$. 


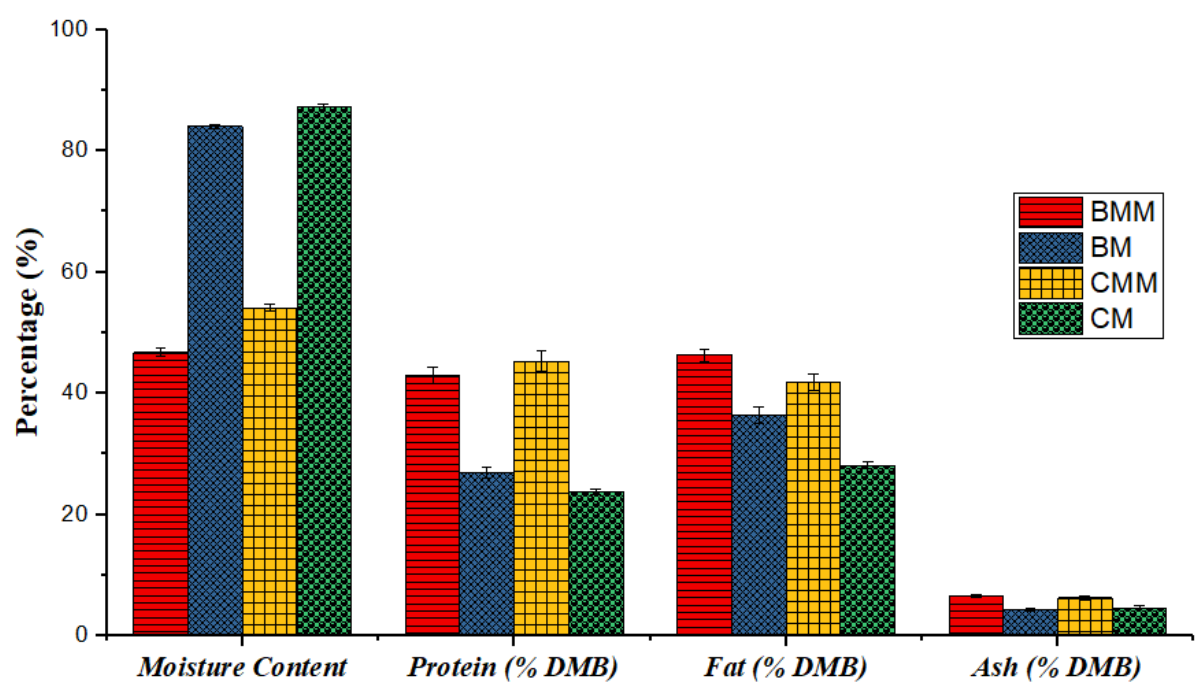

Figure 2. Influence of milk source on the chemical composition of mozzarella cheese.

Protein content: The total protein content of BMM cheese was in a range between 37.00 and $49.10 \%$, while in the case of CMM cheese it varied between 35.70 to $50.00 \%$. The average total protein content on Dry Matter Base $(\%$ DMB) of BMM cheese $(42.87 \pm 1.39 \%)$ was lower than that of CMM cheese $(45.27 \pm 1.65 \%)$ and the difference among them was insignificant $(\mathrm{P}>0.05)$. The average protein content in buffalo milk (26.92 $\pm 0.92 \%)$ was recorded although high but not statistically different from that of cow milk $(23.80 \pm 0.49 \%)$ and depicted in Figure 2 and Table 1. However, a significant increase in the protein content was noted of both types of mozzarella cheeses against their corresponding milk, nevertheless, this increase in mozzarella cheeses was recorded inverse.

Fat content: The average fat content of CMM cheese $(41.82 \pm 1.31 \%)$ was recorded substantially $(\mathrm{P}<0.05)$ lesser than that of BMM $(46.32 \pm 1.02 \%)$. The minimum fat content in BMM cheese was examined as $40.60 \%$ and the maximum $51.80 \%$, whereas the minimum fat content in CMM cheese was observed as $36.20 \%$ and the maximum $46.90 \%$. Fat content was observed considerably $(\mathrm{P}<0.05)$ higher in buffalo milk $(36.34 \pm 1.36 \%)$ in contrast to that of cow milk $(28.18 \pm 0.61 \%)$ and it was increased considerably in mozzarella cheese with a similar trend to that of their corresponding milk (Figure 2, Table 1).

Ash content: The minimum and maximum ash content of BMM cheese were 5.30 and $7.80 \%$, and in the case of CMM cheese, it was 4.50 and $7.20 \%$, respectively. Regardless, the average ash content of CMM cheese $(6.23$ $\pm 0.28 \%$; DMB) was found lower than that of BMM cheese $(6.52 \pm 0.24 \%$; DMB $)$, the least significant difference test (LSD 0.05) revealed non-substantial variations among them. However, the concentration of ash content in both mozzarella cheeses were appeared considerably high against their corresponding controls i.e. buffalo milk ( $4.27 \pm 0.21 \%)$ and cow milk (4.67 $\pm 0.27 \%)$ and presented in Figure 2 and Table 1.

\section{Rheological attributes of mozzarella cheese}

Meltability: The meltability of CMM cheese was observed between 3.00 and $4.00 \mathrm{~cm}$ and that of BMM cheese, it was in a range of 2.40 and $3.20 \mathrm{~cm}$. The average meltability of CMM cheese $(3.41 \pm 0.13)$ remained statistically high $(\mathrm{P}<0.05)$ than that of BMM cheese $(2.87$ $\pm 0.08)$ and is depicted in Figure 3 and Table 1.

Stretchiness: The minimum and maximum stretchiness of mozzarella cheese made from cow milk was observed as 6.00 and $9.00 \mathrm{~cm}$, whereas in BMM cheese, it was ranged between 4.00 and $8.00 \mathrm{~cm}$, respectively. The average stretchiness of mozzarella cheese made from cow milk $(7.65 \pm 0.33 \mathrm{~cm})$ was noticeably $(\mathrm{P}<0.05)$ greater than that of $\mathrm{BMM}$ cheese i.e. $6.45 \pm 0.36 \mathrm{~cm}$ (Figure 3 and Table 1 ).

\section{Organoleptic analysis of mozzarella cheese}

Appearance: The score for BMM cheese ranged between 9.00 and 13.00 and averaged $10.81 \pm 0.36$. Whereas the appearance score of CMM cheese was between 10 and 14 with an average score of $11.86 \pm 0.41$ over a score of 15 (Figure 4 and Table 1). Statistically, non-significant $(\mathrm{P}>0.05)$ variation among both types of mozzarella cheeses were found, regardless of the appearance score rated high for cow milk mozzarella cheese.

Color: The color score of BMM cheese ranged between 5.00 and 8.00 with an average score of $6.80 \pm$ 0.30 , whereas it was between 6 and 9 , and averaged 7.70 \pm 0.28 for CMM cheese over a score of 10 (Figure 4 and Table 1). The average score perceived by CMM cheese was found substantially higher $(\mathrm{P}<0.05)$ than the BMM cheese. 


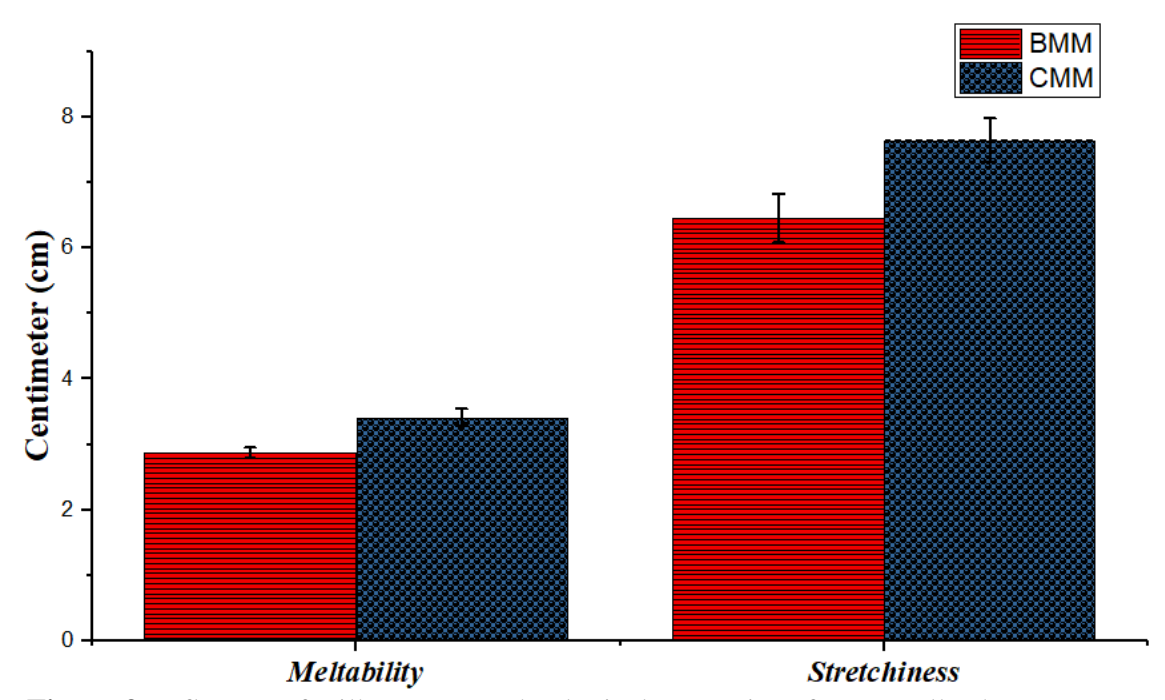

Figure 3. Influence of milk source on rheological properties of mozzarella cheese.

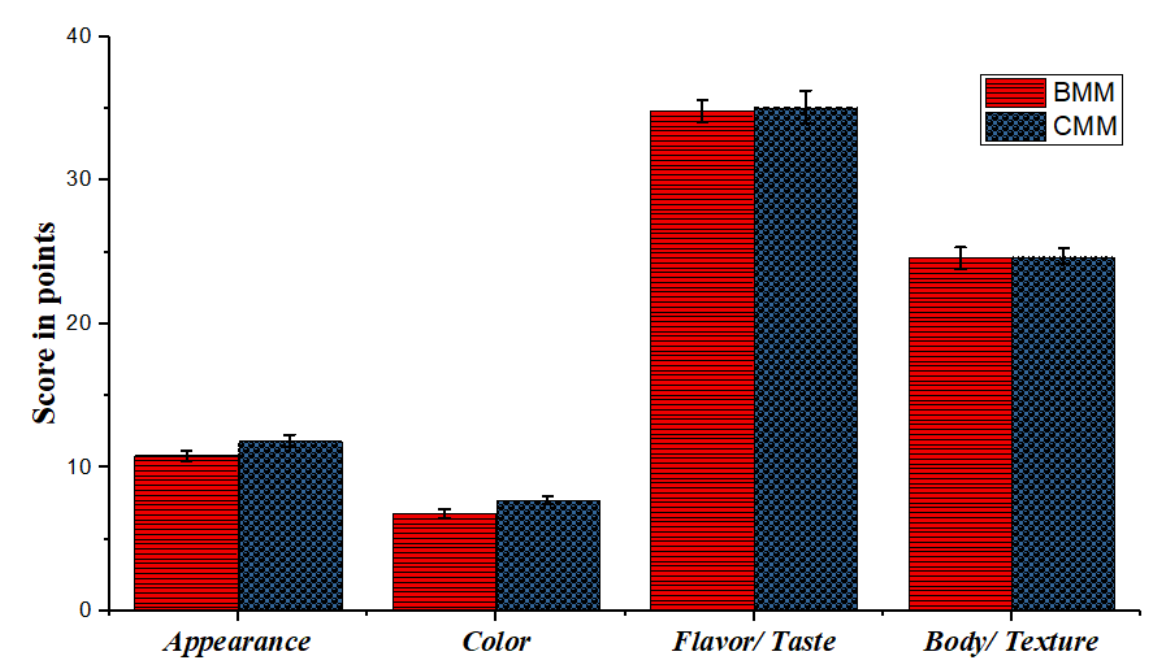

Figure 4. Influence of milk source on organoleptic attributes of mozzarella cheese.

Flavor/Taste: The score evaluated for the flavor/taste of BMM cheese varied between 30.50 and 38.50, whereas that of CMM cheese, was between 29.00 and 40.00 over a score of 45 . BMM cheese $(34.80 \pm 0.79)$ perceived a slightly lower score as compared to that of CMM cheese $(35.10 \pm 1.13)$, but the difference is not significant (Figure 4 and Table 1).

Body/Texture: The score rated for body/texture of BMM cheese varied between 20.00 and 28.00 , while that of rated for CMM cheese, it was in between 21.00 and 27.50 over a score of 30 . Mean score of body/texture of BMM cheese $(24.56 \pm 0.77)$ was found comparatively analogous $(\mathrm{P}>0.05)$ to that perceived by $\mathrm{CMM}$ cheese i.e. $24.70 \pm 0.54$ (Figure 4 and Table 1).

The yield of mozzarella cheese: The minimum yield of BMM cheese was observed as $13.75 \%$ and the maximum $20.00 \%$, while the minimum yield of CMM cheese was recorded as $9.00 \%$ and the maximum $14.20 \%$. Buffalo milk on average yielded considerably $(\mathrm{P}<0.05)$ higher quantity of mozzarella cheese $(16.95 \pm 1.29 \%)$ than that made from cow milk i.e. $12.68 \pm 0.936 \%$ (Figure 5 and Table 1).

Calorific values of mozzarella cheese: The range of calorific values ( $\mathrm{kcal} / 100 \mathrm{~g}$ ) of BMM cheese was between 283.40 and 351.00, while in CMM cheese, it varied between 241.00 to $299.00 \mathrm{kcal} / 100 \mathrm{~g}$. The average calorific value $(\mathrm{kcal} / 100 \mathrm{~g})$ of BMM cheese $(318.49 \pm$ $6.42 \mathrm{kcal} / 100 \mathrm{~g})$ was considerably $(\mathrm{P}<0.05)$ higher than the CMM cheese $(268.83 \pm 5.085 \mathrm{kcal} / 100 \mathrm{~g})$. However, both cheeses appeared considerably $(\mathrm{P}<0.05)$ high in calorific values from that of their corresponding milk i.e. buffalo milk $(89.79 \pm 1.14 \mathrm{kcal} / 100 \mathrm{~g})$ and cow milk $(65.72 \pm 1.33 \mathrm{kcal} / 100 \mathrm{~g})$, presented in Figure 6 and Table 1. 


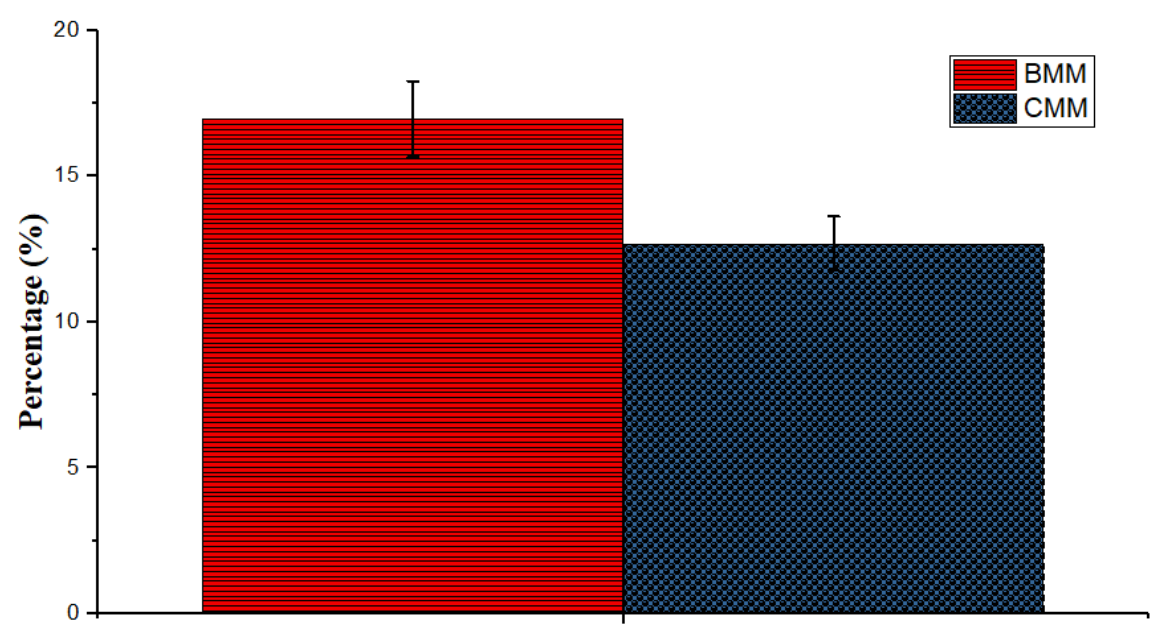

Figure 5. Yield (\%) of mozzarella cheese made from buffalo and cow milk.

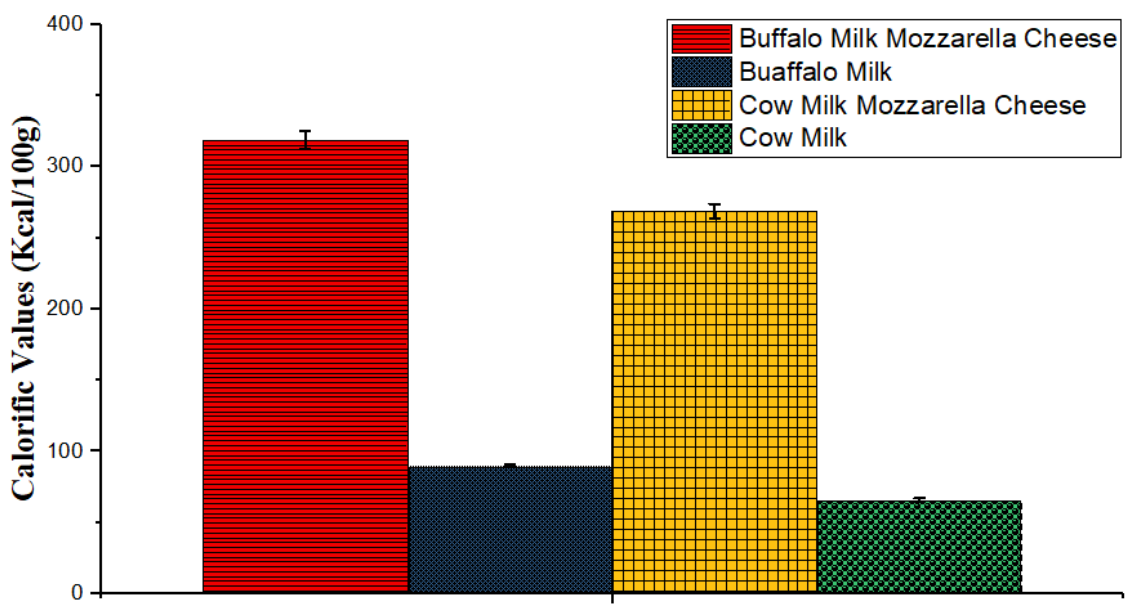

Figure 6. Calorific values of mozzarella cheese made from buffalo and cow milk.

Table 2. Economic Analysis of mozzarella cheese made from cow and buffalo milk.

\begin{tabular}{|c|c|c|c|c|c|c|c|c|}
\hline \multirow{2}{*}{$\begin{array}{c}\text { Economic } \\
\text { Markers }\end{array}$} & \multirow[t]{2}{*}{ Component } & \multicolumn{3}{|c|}{ BMM cheese } & \multicolumn{4}{|c|}{ CMM cheese } \\
\hline & & Quantity & $\begin{array}{l}\text { Rate } \\
\text { (Rs) }\end{array}$ & $\begin{array}{c}\text { Amount } \\
\text { (Rs) }\end{array}$ & Quantity & $\begin{array}{l}\text { Rate } \\
\text { (Rs) }\end{array}$ & $\begin{array}{c}\text { Amount } \\
\text { (Rs) }\end{array}$ & $\mathbf{P}$ \\
\hline \multicolumn{9}{|l|}{ Cost (Rs) } \\
\hline & Milk & $4 \mathrm{~kg}$ & 70 & 280.0 & $4 \mathrm{~kg}$ & 60 & 204.00 & - \\
\hline & Rennet & 1/8 tablet & 250/ tablet & 31.25 & 1 tablet & 250/ tablet & 31.25 & - \\
\hline & Starter Culture & $120 \mathrm{~g}$ & - & 5.46 & $120 \mathrm{~g}$ & - & 4.76 & - \\
\hline & Miscellaneous & - & - & 183.35 & - & - & 163.005 & - \\
\hline & Total (A) & - & - & 550.06 & - & - & 489.01 & - \\
\hline \multicolumn{9}{|l|}{ Income (Rs) } \\
\hline & Cheese (B) & $0.67 / \mathrm{kg}$ & $1400 / \mathrm{kg}$ & 935.20 & $0.507 \mathrm{~kg}$ & $1400 / \mathrm{kg}$ & 710.92 & 0.050 \\
\hline \multicolumn{9}{|l|}{ Benefit (Rs) } \\
\hline & $(\mathrm{B}-\mathrm{A})$ & - & - & 385.14 & - & - & 221.91 & 0.217 \\
\hline
\end{tabular}

Economic of Mozzarella cheese: The total expenditure to produce BMM cheese (Rs 550.06) appeared slightly higher than that of CMM cheese (Rs 489.01). However, the income was computed considerably high in BMM cheese (Rs 935.20) than that of CMM cheese (Rs 710.92). Regardless, the remarkable variation occurred between the incomes of BMM cheese and CMM cheese, the expected benefit was not significant among them i.e. Rs $385.14 \pm 81.0$ and $221.91 \pm 52.67$, respectively (Table 2). 


\section{Discussion and Conclusion}

Chemical analysis of BMM and CMM cheeses: The significant influence of milk source was noted on the moisture content of mozzarella cheeses. Mozzarella cheese prepared from cow milk appeared high in moisture content compared to that of BMM cheese. This is because of the composition of their corresponding milk from which these were manufactured. A similar trend of moisture content was recorded in the milk of buffalo and cow whereby cow milk appeared high in moisture content than that of buffalo milk in the current study. However, a remarkable decrease in the moisture content of mozzarella cheese was noted either prepared from cow milk or/buffalo milk. This decrease in moisture content could be associated with the removal of whey from coagulated curd, and consequently, the increase in total solids content was observed in the final product. The majority of mozzarella cheese batches were consistent with the findings described by Sameen et al. (21) and Sulieman et al. (24), i.e. 52.44 and $50.49 \%$, respectively.

In the present study, comparatively high protein content was noted in mozzarella cheese from that of their corresponding milk. However, protein content in mozzarella cheese was found inverse compared to that observed in milk. CMM cheese appeared slightly higher in protein content than that of BMM cheese, whereby their corresponding milk appeared opposite in protein content i.e. marginally better protein content in buffalo milk. Nevertheless, the variation between the protein content of both types of cheeses and/or kinds of milk existed statistically non-significant $(\mathrm{P}>0.05)$. It is noteworthy that a slight variation in protein content of mozzarella cheese manufactured from two different milk sources may be attributed to the casein content of milk that may have not been properly recovered from buffalo milk and/or whey proteins during pre-heat treatment of buffalo milk which may have not been denatured. Several factors have been reported in different studies, for instance, protein degradation may occur as heat treatment increases, and that the rate of amino acid liberation decreases as heat treatment increases (23). Variation in mozzarella cheese protein content may also occur either due to crude enzyme extract and/or withholding of whey in the finished product (cheese) that might enhance the protein content (16).

A significant influence of milk sources was noted on the fat content of mozzarella cheese. BMM cheese appeared markedly high in fat content than the CMM cheese, is due to the composition of the corresponding milk from which they were manufactured. A similar trend of fat content was recorded in the milk of buffalo and cows. However, a considerable decrease in the fat content of BMM and CMM cheeses was noted. It is interesting to note that an increase in milk component among total solids content may occur if one of the components decreases in proportion from its original proportion, and in the current study whey protein along with lactose content may have been drained in whey liquid during the manufacturing of mozzarella cheese, and in a consequence increase in other components might have been occurred. Similar sorts of outcomes were reported by Bhattarai and Acharya (8), Mijan et al. (18) and Sameen et al. (21) i.e. 42.81 to 52.9\%, (on DMB).

The ash content of BMM cheese appeared higher in contrast to that of CMM cheese. The variation in ash content in both types of mozzarella cheese existed nonsignificant. This could be due to the composition of the corresponding milk from which these were manufactured. A similar trend of ash content was recorded in the milk of buffalo and cow, whereby cow milk appeared slightly high in ash content than that of buffalo milk but statistically non-significant $(\mathrm{P}>0.05)$. However, the average value of $\mathrm{BMM}$ and $\mathrm{CMM}$ cheeses were $(6.52 \pm 0.238$ and $6.23 \pm$ $0.278 \% \mathrm{DMB})$ in accordance with the outcomes described by Bhattarai and Acharya (8) and Mijan et al. (18), i.e. $7.7 \%$ and $8.1 \%$ DMB $4.8 \%$ and $5.1 \%$ DMB.

Rheological analysis of BMM and CMM cheeses: The amount of cheese flow and spreading upon exposure to heat is the chief functional attribute of mozzarella cheese termed as "meltability" (21). This property although varied between the cow and buffalo milk mozzarella cheese, the difference among them was found significant. It is noteworthy that variation in meltability of BMM cheese and CMM cheese is due to a decrease in calcium content and higher moisture content present in cow milk, while it might have been improved through the removal of the para-casein matrix (19). Nevertheless, current results of meltability agreed with the results observed by Bertola et al. (6) and Bhattarai and Acharya (8), i.e. $3.4 \mathrm{~cm}$, and $3.06,4.33 \mathrm{~cm}$, respectively.

The stretchiness of CMM cheese was significantly higher than the BMM cheese. The increased stretchiness of CMM cheese could be attributed to the reduction in the calcium level that causes a decrease in the structural strictness of the cheese matrix subsequently enhancing the stretchiness (8). During ripening, proteolysis results in increased porosity of the casein matrix, and therefore resistance to stretching has reduced (6). The current results are in agreement with the outcomes reported by Bhattarai and Acharya (8) which suggests that cheese with greater meltability had higher stretchiness.

Impact of milk source on yield and calorific values of BMM and CMM cheeses: BMM cheese appeared although high in yield contrast to CMM cheese, the difference among them existed non-significant. This is possibly due to the composition of their corresponding milk from which these were manufactured, whereby buffalo milk was significantly high in TS content than that of cow milk. It is of interest to note that the yield of cheese 
is dependent on the recovery percentage of solids, whereby the greater the number of recovered solids, would yield a higher amount of cheese, and this has also been reported in a previously conducted study (13), whereby the recovered amount of cheese was recorded highest from buffalo milk and the lowest from cow milk. Another factor that might involve yield is the use of rennet that enhances the whey separation from the curd and prevent the excess loss of casein protein $(7,14)$.

A significant influence of milk source was noted on calorific values of mozzarella cheese. Calorific values of $\mathrm{BMM}$ cheese were significantly higher than the CMM cheese. The difference in calorific values of cheeses in the present study corresponds to the milk source from which those were prepared, whereby buffalo milk appeared considerably high in energy value than the cow milk. A similar trend in the energy value of buffalo and cow milk was reported (4). Moreover, researchers had confirmed the present finding, who reported a remarkable proportion of calories in buffalo milk $(3450 \mathrm{KJ} / \mathrm{Kg})$ than the cow milk (3169 KJ /Kg). Moreover, it has been described that in terms of calories per unit weight, buffalo milk is superior to cow milk due to its better chemical composition (20).

Organoleptic analysis of BMM and CMM cheeses: Organoleptic attributes like appearance and flavor/taste are the most important factor in determining consumer's responses. It has been described that the flavor of mozzarella cheese made from cow milk is liked more by most of the panelists (11). Moreover, in the present study appearance, flavor/taste, and body/texture score rated for CMM cheese and BMM cheese varied slightly, although the difference among them appeared non-significant. A significant difference was noted in the color of BMM cheese and CMM cheese. The CMM cheese appeared yellowish-white as compared to BMM cheese which was white. The color differences are possible due to carotene content which is rich in cows' milk (18).

Economic value of BMM and CMM cheeses: Economics is a knowledge concerned with the production, consumption, and transfer of wealth. The cost of BMM cheese was marginally higher as compared to the CMM cheese. This variation in cost may be due to the higher market price of buffalo milk. The difference between the income and benefit of BMM cheese and CMM cheese was insignificant. The income and profit were somewhat better in BMM cheese as compared to CMM cheese and is due to a higher yield in BMM cheese. The better chemical composition of buffalo milk renders it extremely appropriate for cheese and dairy processing. $1 \mathrm{~kg}$ of cheese production consumes 5 liters of buffalo milk as compared to $8 \mathrm{~kg}$ of cow milk which makes buffalo milk more valuable for processors (4).

It is concluded from the present study that milk sources had a prominent influence on the chemical characteristics and calorific values of mozzarella cheese. Fat, mineral/ash, and calorific values were found considerably high in BMM cheese in contrast to that of CMM cheese. The protein content and stretchiness of CMM cheese appeared significantly better compared to that of BMM cheese. CMM cheese although received a better organoleptic score, but statistically not different from the BMM cheese. Buffalo milk yielded more quantity of mozzarella cheese as well as economic values compared to that of cow milk.

\section{Financial Support}

This research received no grant from any funding agency/sector.

\section{Ethical Statement}

This study does not present any ethical concerns.

\section{Conflict of interest}

The authors declared that there is no conflict of interest.

\section{References}

1. Abegaõ LMG, Pagani AAC, Zílio SC, et al (2016): Measuring milk fat content by random laser emission. Sci Rep, 6, 35119.

2. Ah J, Tagalpallewar GP (2017): Functional properties of Mozzarella cheese for its end use application. J Food Sci Technol, 54, 3766-3778.

3. Al-Amiri HA, Al-Otaibi JA, Al-Foudari MY, et al (2009): The nutritive value of selected commonly consumed Kuwaiti dishes. Int J Food Sci Nutr, 60, 668-676.

4. Anonymous (1981): The Water Buffalo: New prospect for underutilized animal. National Academy Press, Washington, D.C.

5. AOAC (2000): Official methods of analysis of AOAC International. 17th ed. AOAC International, Gaithersburg.

6. Bertola NC, Califano AN, Bevilacqua AE, et al (1996): Effect of Freezing Conditions on Functional Properties of Low Moisture Mozzarella Cheese. J Dairy Sci, 79, 185-190.

7. Bezie A, Regasa H (2019): The Role of Starter Culture and Enzymes/ Rennet for Fermented Dairy Products Manufacture-A Review. Nutr Food Sci, 9, 21-27.

8. Bhattarai RR, Acharya PP (2010): Preparation and Quality Evaluation of Mozzarella Cheese from Different Milk Sources. J Food Sci Technol Nepal, 6, 94-101.

9. BSI (1990): Methods for chemical analysis of liquid milk and cream. Determination of the nitrogen content of liquid milk. Part 5.2, Routine method. British Standards Institution, London.

10. Cais-Sokolińska D, Pikul J (2009): Cheese meltability as assessed by the Tube Test and Schreiber Test depending on fat contents and storage time, based on curd-ripened fried cheese. Czech J Food Sci, 27, 301-308.

11. Clark S, Costello M (2009): Dairy products evaluation competitions. In: The Sensory Evaluation of Dairy Products Springer US. 43-71. 
12. Dave RI, Sharma P, Muthukumarappan K (2003): Effects of Starter Culture and Coagulating Enzymes on Viscoelastic Behavior and Melt of Mozzarella Cheese. J Food Sci, 68, 1404-1410.

13. El-Gawad MAMA, Nawal SA (2011): Cheese Yield as Affected by some Parameters. Acta Sci Pol Technol Aliment, 10, 131-153.

14. El Owni OAO, Osman SE (2009): Evaluation of chemical composition and yield of mozzarella cheese using two different methods of processing. Pak J Nutr, 8, 684-687.

15. Ibrahim AA (2003): Effect of Processing and Storage Condition on the Chemical Composition and Microbial Quality of White Soft Cheese. University of Khartoum, Sudan.

16. Jeewanthi RKC, Lee NK, Mok BR, et al (2016): Comparative analysis of mozzarella cheeses fortified with whey protein hydrolysates, diverse in hydrolysis time and concentrations. J Food Sci Technol, 53, 3566-3573.

17. Li R, Yu K, Li C (2018): Dietary factors and risk of gout and hyperuricemia: A meta-analysis and systematic review. Asia Pac J Clin Nutr, 27, 1344-1356.

18. Mijan M, Haque M, Habib M, et al (2010): Evaluation of quality of mozzarella cheese. Bangladesh Vet, 27, 36-42.
19. Perna A, Simonetti A, Intaglietta I, et al (2014): Effects of genetic type, stage of lactation, and ripening time on Caciocavallo cheese proteolysis. J Dairy Sci, 97, 19091917.

20. Sahai D (1996): Buffalo Milk Chemistry and Processing Technology. Karnal Shalini International (SI) Publications, India.

21. Sameen A, Anjum FM, Huma N, et al (2008): Impact of Fat Levels in Milk on the Composition, Sensory Attributes and Functionality of Buffalo Mozzarella Cheese. Pak J Agric Sci, 45, 463-469.

22. Schiano AN, Harwood WS, Drake MA (2017): A 100Year Review: Sensory analysis of milk. J Dairy Sci, 100, 9966-9986.

23. Shimamura T, Uke H (2012): Maillard Reaction in Milk. In: Walter L. Hurley (Ed), Effect of Heat Treatment, Milk Protein. IntechOpen.

24. Sulieman AME, Ali AMR, Razig AAK (2012): Production and Effect of Storage in the Chemical Composition of Mozzarella Cheese. Int J Food Sci Nutr Eng, 2, 21-26. 